\title{
HYALURONIC ACID, SPLEEN SIZE AND PROTHROMBIN TIME PREDICT THE EXISTENCE OF HIGH-RISK ESOPHAGEAL VARICES IN NON-VIRAL CIRRHOSIS IN REAL LIFE
}

\author{
Silvia Sovaila ${ }^{1}$, Adrian Purcarea ${ }^{2}$, Jean Pierre Fauchart², Dan Gheonea ${ }^{1}$, Tudorel Ciurea ${ }^{1}$ \\ ${ }^{1}$ University of Medicine and Pharmacy of Craiova, Craiova, Romania \\ ${ }^{2}$ Hospital of Charleville-Mezieres, Charleville-Mezieres, France \\ Corresponding author: \\ Silvia Sovaila \\ E-mail: silvia.sovaila@internist.com
}

\begin{abstract}
Background and aims. Biomarkers are a simple and inexpensive way to replace the invasive diagnostic test ${ }^{(1,2)}$. Portal hypertension screening recommendations in cirrhotic patients propose two such biomarkers: the platelet count and liver elastography. This recommendation derives from studies on viral cirrhosis ${ }^{(3)}$. Viral cirrhosis is biologically and histologically different from steatosis related cirrhosis and traditional biomarkers used for high-risk varices screening might not be of use in this category. We aimed to evaluate their utility compared to other biomarkers for the prediction of high-risk varices of non-viral etiology in cirrhotic patients.
\end{abstract}

Methods. Our current study is a monocentric, real-life, cross-sectional analysis of non-viral cirrhosis patients.

Results. 50 patients with suspected cirrhosis, who underwent upper gastrointestinal endoscopy, were included prospectively for over 8 months and 41 were analyzed. The etiology was steatohepatitis (alcohol and non-alcohol related steatohepatitis). Hyaluronic acid (AUC 0.866, $r=0.600$ ), prothrombin time (AUC 0.708, $r=0.445$ ) and spleen size (AUC $0.763, r$ $=0.337$ ) significantly correlated with high-risk esophageal varices. In the meantime, liver stiffness was difficult to obtain and only correlated modestly with high-risk esophageal varices and platelet count was a poor predictor of high-risk esophageal varices in this mainly steatosis related cohort of cirrhotic patients.

Conclusion. We proposed hyaluronic acid, spleen size and prothrombin time as alternatives biomarkers for portal hypertension in steatohepatitis patients. Their potency should be further proven in larger studies.

Keywords: portal hypertension, hyaluronic acid, biomarkers. 


\section{INTERNAL}

\section{Original papers}

\section{Rezumat}

Introducere și obiective. Biomarkerii sunt o modalitate simplă și ieftină de a înlocui testele de diagnostic invazivi, ${ }^{(1,2)}$. Recomandările de depistare a hipertensiunii portale la pacienții cirotici propun doi astfel de markeri: numărul de trombocite și elastografia hepatică. Aceste recomandări derivă în principal din studii efectuate pe pacienți cu ciroză de etiologie virală(3), însă ciroza virală este diferită biologic și histologic de steatoză. Ne-am propus să evaluăm utilitatea acestora în comparație cu alți biomarkeri pentru predicția varicelor cu risc ridicat la pacienții cu ciroză de etiologie non-virală.

Metodă. Studiul nostru actual este o analiză mono-centrică, reală, în secțiune transversală a pacienților cu ciroză non-virală.

Rezultate. Un număr de 50 de pacienți cu ciroză suspectată, care au realizat endoscopie gastrointestinală superioară, au fost incluși prospectiv timp de peste 8 luni, 41 au fost analizați. Etiologia a fost steatohepatita (alcool și steatohepatită non-alcoolică). Acidul hialuronic (ASC 0,866, $r=0,600$ ), timpul de protrombină (AUC 0,708, $r=0$,445) și mărimea splinei (ASC 0,763, $r=0,337)$ au fost corelate semnificativ cu varice esofagiene cu risc ridicat. Elastografia hepatică a fost dificil de efectuat și a fost slab corelată cu varicele esofagiene cu risc ridicat. Numărul de trombocite a fost un predictor slab al varicelor esofagiene cu risc ridicat în această cohortă de pacienți cirotici.

Concluzie. Propunem acidul hialuronic, timpul de protrombină și dimensiunea splinei ca markeri alternativi pentru hipertensiunea portală la pacienții cu ciroză secundară steatohepatitei. Valoarea lor ar trebui validata și în alte studii pe populații mari.

Cuvinte cheie: hipertensiune portală, acid hialuronic, markeri. 


\section{Introduction}

Portal hypertension is one of the main complications of cirrhosis, independent of the etiology and has a mortality rate of 15$20 \%$ at 30 days in the presence of acute variceal bleeding ${ }^{(4,5)}$. Primary prevention of variceal bleed with beta blockers and/ or endoscopic band ligation remains the cornerstone of treatment. It relies on the scenting capacity of at-risk patients. Until recently, screening for clinically significant portal hypertension and high-risk varices relied on an invasive endoscopic procedure ${ }^{(6)}$. The 2015 Baveno VI consensus on portal hypertension proposed, for the first time, non-invasive biomarkers (thrombocytes and liver stiffness) to better target patients at risk $^{(3)}$. There is a high sensitivity and low specificity combination extracted mainly from cohorts and RCT with a predominant viral etiology. We expected that this combination of biomarkers performed even less well in steatosis-related cirrhosis. The aim of our study was to evaluate clinical and biological markers that might correlate with high-risk varices of non-viral etiology in cirrhotic patients.

\section{Patients and methods}

\section{Patients and settings}

Our current study is a predefined crosssectional analysis of a monocentric, real-life, and cohort study of non-viral cirrhosis patients. All patients with suspected cirrhosis, who underwent upper gastrointestinal endoscopy, were included prospectively over 8 months in late 2016 and early 2017, in a Gastroenterology Department of a regional (secondary care) hospital in France. Patients were excluded if their age was below 18 years, presented a medical condition with a life expectancy less than 3 months, had a history of variceal bleed or prophylactic ligature prior to the inclusion endoscopy or a low probability of cirrhosis.

Cirrhosis was suspected when clinical biology of signs of liver disease were present, the patient had a history of liver disease or exposure to toxics, and two non-invasive fibrosis tests were not in favor of only limited liver disease (FIB4 test $<1.45$ or an APRI score less than 0.5$)^{(7,8)}$.

The study protocol was accepted by the Ethics Committee of the facility (June 2016), and the explorations were considered part of the standard clinical practice (articles L.1121-1 paragraph 1 and R1121-2, French Public Health Code). Patients' informed consent was waived. Data was analyzed in anonymized format.

The primary outcome was the analysis different markers (clinical, biological, radiologic or composite) with respect to the existence of high-risk varices in patients with non-viral cirrhosis.

\section{Data collection and Variables Upper GI endoscopy}

According to the guidelines of "Société Nationale Française de Gastro-Entérologie (SNFGE)", endoscopic examinations of the esophagus, stomach and duodenum were performed using an Exera III (Olympus TM), by any one of the four local gastroenterologists and specific changes were documented (photographs). Varices were classified into absent, small, medium or large and the presence of red whale marks was noted according to international standards. We referred to "high-risk varices" in the presence of medium or large varices or small varices with red whale marks ${ }^{(9)}$. 


\section{INTERNAL}

\section{Original papers}

\section{Biomarkers}

The following biological markers were documented: Haemoglobin, haematocrit, platelet number, aspartate-aminotransferase (AST) and alanine aminotransferase (ALT), gamma glutamyl transpeptidase (GGT), alkaline phosphatase (PA), Prothrombin Time (TP), hyaluronic acid, brain natriuretic peptide (BNP), total cholesterol, alpha 2 macroglobulin, total bilirubin, haptoglobin, apolipoprotein A2, C reactive protein (CRP), erythrocyte sedimentation rate (VSH). All tests were performed by the hospital's accredited laboratories.

The following variables were considered potential confounders and recorded: demographics, comorbidity, treatment at inclusion, current alcohol consumption, previous medical history, vital and clinical signs, suspected infection and site, laboratory data. Data on each of these factors was collected from the patient's medical record.

The composite scores computed and used were: $\mathrm{APRI}^{(8)}$, Hepascore ${ }^{(10,11)}, \mathrm{FIB} 4^{(7)}$ MELD $^{(12)}$, Child Pugh ${ }^{(13,14)}$, Charlson comorbidity index ${ }^{(15)}$, LOK, FORNS ${ }^{(16)}$.

Imaging studies documenting liver and portal size, spleen size with bipolar diameter and portal hypertension signs were performed in all patients (ultrasound, CT scans or abdominal MRI) according to the treating physicians' judgement.

Liver stiffness was assessed in either inpatient or outpatient manner by transient elastography (TE) with a standard probe by one experienced operator, blinded to study data (Fibroscan, Echosens, 402 model) and results were registered as kilopascals (KP) and interquartile range (IQR). Reasons for failure were detailed but the absence of Fibroscan measurements was not considered a reason for exclusion.

Biopsy and HPVG measurements were not performed as standard of care but could be proposed as clinically needed.

Blinding. Professionals performing all laboratory tests and imaging techniques were kept blinded to the subjects' demographics, clinical and endoscopy data. Professionals performing endoscopy were blinded to protocol related biological and imaging data.

\section{Statistical analysis}

Statistical analysis was performed using SPSS v22.0 (IBM, Chicago, Illinois) and a twotailed $p$-value $<.05$ was considered significant. The descriptive data with normal distribution is presented as Mean - Standard Deviation while the non-normally distributed data is presented as Median and IQR. Missing values and outliers were replaced by the sum 


\begin{tabular}{|c|c|}
\hline \multicolumn{2}{|c|}{ Baseline population } \\
\hline Age (years) & $60.15(12.11)$ \\
\hline Male gender $(\%)$ & $31(64 \%)$ \\
\hline $\mathrm{BMI}^{\#}$ & $26.6(6.68)$ \\
\hline Oedema (\% present) & $20(41 \%)$ \\
\hline Encephalopathy (\% present) & $6(12 \%)$ \\
\hline Collateral circulation (\% present) & $23(48 \%)$ \\
\hline Ascites ( $\%$ absent/ $\%$ controlled/ $\%$ resistant) & $17(41.5 \%) / 15(36.6 \%) / 9(22 \%)$ \\
\hline Albumin $(\mathrm{g} / \mathrm{dl})^{\#}$ & $29.34(7.57)$ \\
\hline Bilirubin (mg/ dl) & $20.36(20.34)$ \\
\hline Prothrombin Time $(\%)^{\#}$ & $66.77(22)$ \\
\hline Creatinine (mmol/ I) & $76.74(42.45)$ \\
\hline Hemoglobin $(\mathrm{g} / \mathrm{dl})^{\#}$ & $10.73(2.15)$ \\
\hline Platelets $\left(10^{9} / \mathrm{cm}^{3}\right)$ & $150.26(94.78)$ \\
\hline AST (UI/ I) ${ }^{\#}$ & $56.55(29.12)$ \\
\hline ALT (UI/ I) & $30.36(17.64)$ \\
\hline GGT (UI/ I) & $206.23(37.33)$ \\
\hline FA (UI/ I) & $123.5(83)$ \\
\hline Hyaluronic acid (mcg/l) & $657(1168)$ \\
\hline Fibroscan (kP) \# & $48(5.08)$ \\
\hline MELD & $10.13(2.4)$ \\
\hline CHILD $^{\#}$ & $7.77(1.9)$ \\
\hline Hepascore & $1(0.08)$ \\
\hline Forns $^{\#}$ & $10.37(1.69)$ \\
\hline LOK & 0.95 \\
\hline FIB4 & $5.58(4.23)$ \\
\hline APRI & $1.51(1.33)$ \\
\hline
\end{tabular}

Table 1. Patients demographics. Clinical markers presented as \% per total. The results are presented as median/ IQR for markers with non-normal distribution and Mean/ SD for normal distribution (\#) 


\section{INTERNAL}

\section{Original papers}

of means for each variable. Differences between groups were analyzed using the Mann-Whitney $U$ test, Fisher's exact test or chi-square. The strength of correlation with the primary outcome was assessed using the Pearson's $r$ or Spearman's rho correlation coefficients. The area under the receiver operated curve was computed and cut-off values for a maximal sum of sensitivity and specificity and absolute positive and negative prediction values were extracted. For variables significantly associated with high-risk varices in univariate analysis, a multivariate binary logistic regression was performed.

\section{Results}

\section{Baseline characteristics}

During the study period, 50 patients met the inclusion criteria. Of these, 2 were excluded before endoscopy ( 1 had active cancer, 1 refused participation) and a total of 48 patients were considered for inclusion. After endoscopy and liver tests, 7 patients were excluded based on a low non-invasive cirrhosis probability (FIB $4<1.45$ or APRI $<0.5$ ). The remaining 41 patients were analyzed.

In our population, $64 \%$ were men, the mean age was 60 years and the Charlson Comorbidity Index was 4.6. 25 patients mainly had alcohol related liver disease, 6 had an obesity related disease and 10 had a mixed non-alcohol and alcohol related disease. The mean Child Score value was 7.8 to a maximum of 12 (Table 1 ).

Endoscopy was performed in all patients. Portal hypertension signs were present in 30 (73\%) of the 41 patients. 10 patients $(24.4 \%)$ had portal hypertension gastropathy, 25 (61\%) had esophageal varices, with 19 $(46.3 \%)$ having grade 2 or more. No gastroesophageal varices or isolated gastric varices were present.

Patients $(\mathrm{N}=41)$ were then split into two groups: high-risk varices $(n=19)$ and low-risk varices $(n=22)$. The 7 patients excluded (with low cirrhosis probability) had no varices.

\section{High risk varices versus low-risk varices}

There were no clinical differences between the low risk and high-risk varices groups with regard to heart rate, ascites, encephalopathy, edema and collateral circulation. Thrombocyte levels, liver stiffness, liver enzymes, bilirubin, apolipoprotein $A 2$, albumin and alpha 2 macroglobulin were not significantly different although some trends were visible. Spleen size, hyaluronic acid and TP were the biomarkers significantly different between groups (Table 2 ). The differences maintained 


\begin{tabular}{|c|c|c|c|c|c|}
\hline \multirow[b]{2}{*}{ Edema (\%) } & \multicolumn{2}{|c|}{$\begin{array}{l}\text { High-risk varices } \\
(\mathrm{N}=19)\end{array}$} & \multicolumn{2}{|c|}{$\begin{array}{l}\text { Low risk varices } \\
(\mathbf{N}=22)\end{array}$} & \\
\hline & $10(52 \%)$ & & $10(34 \%)$ & & \\
\hline \multicolumn{6}{|l|}{ Ascites (\%) } \\
\hline - Absent & $7(36 \%)$ & & $10(45 \%)$ & & \\
\hline - Controlled & $8(42 \%)$ & & $7(33 \%)$ & & \\
\hline - Refractory & $4(21 \%)$ & & $5(22 \%)$ & & \\
\hline Collateral circulation (\%) & $12(63 \%)$ & & $11(38 \%)$ & & \\
\hline Encephalopathy (\%) & $3(16 \%)$ & & $3(10 \%)$ & & \\
\hline Thrombocytes (10 / mmc) & 87.5 & 60 & 119 & 71 & .077 \\
\hline Creatinine $(\mu \mathrm{mol} / \mathrm{I})$ & 70 & 39 & 68.5 & 30 & .663 \\
\hline Alkaline phosphatase (UI/ I) & 145 & 88 & 105 & 78 & .089 \\
\hline ALT (UI/ I) & 25.5 & 29 & 26 & 16 & .765 \\
\hline Gamma-GT (UI/ I) & 141 & 209 & 96.5 & 113 & .440 \\
\hline Total bilirubin $(\mu \mathrm{mol} / \mathrm{I})$ & 25 & 25 & 10.93 & 9.88 & .099 \\
\hline Total cholesterol (mmol/ I) & 1.065 & 0.40 & 1.33 & 0.38 & .152 \\
\hline Alpha 2 macroglobulin ( $\mathrm{g} / \mathrm{l})$ & 1.98 & 0.74 & 2.085 & 0.85 & .964 \\
\hline Hyaluronic acid (mcg/l) & 610 & 767 & 147 & 224 & $.000 *$ \\
\hline Procalcitonin (ng/ ml) & 0.105 & 0.07 & 0.125 & 0.1 & .186 \\
\hline Venous lactate (mmol/ I) & 2.3 & 0.9 & 2.4 & 1.2 & .466 \\
\hline Haptoglobin $(\mathrm{mg} / \mathrm{dl})^{\#}$ & 0.72 & 0.57 & 1.02 & 0.40 & .239 \\
\hline Apolipoprotein A2 $(\mathrm{g} / \mathrm{l})^{\#}$ & 0.87 & 0.32 & 1.09 & 0.30 & .054 \\
\hline $\begin{array}{l}\text { Brain natriuretic peptide (pg/ } \\
\mathrm{ml})^{\#}\end{array}$ & 205 & 253 & 132 & 152 & .309 \\
\hline Albumin $(\mathrm{g} / \mathrm{dl})^{\#}$ & 26.89 & 5.7 & 30.86 & 6.95 & .058 \\
\hline $\mathrm{TP}^{\#}$ & 55.84 & 15.15 & 73.74 & 19.44 & $.004 *$ \\
\hline VSH $(\mathrm{mm} / \mathrm{h})^{\#}$ & 37.14 & 32.9 & 21.47 & 15.4 & .078 \\
\hline Haemoglobin $(\mathrm{g} / \mathrm{l})^{\#}$ & 10.15 & 1.88 & 11.24 & 2.28 & .108 \\
\hline AST $\left(U I / I^{\#}\right.$ & 63.61 & 27.98 & 57.41 & 31.71 & .521 \\
\hline LOK & 0.984 & 0.07 & 0.9295 & 0.21 & .053 \\
\hline Hepascore & 1 & 0 & 0.962 & 0.26 & $.001^{*}$ \\
\hline MELD & 12.16 & 3.24 & 10.45 & 4.95 & .067 \\
\hline Child Score $^{\#}$ & 8.11 & 1.32 & 7.69 & 2 & .439 \\
\hline FORNS $^{\#}$ & 11.06 & 1.60 & 9.77 & 1.56 & $.013^{*}$ \\
\hline Spleen size ${ }^{\#}$ & 14.32 & 2.26 & 12.72 & 2.28 & $.031^{*}$ \\
\hline Liver stiffness $(\mathrm{KPa})^{\#}$ & 57.88 & 15.48 & 48.44 & 17.89 & .096 \\
\hline
\end{tabular}

Table 2. High-risk varices versus low risk varices. The results are presented as median/ IQR .p* statistically significant. Mann-Whitney $U$ unless otherwise recommended (\# Normal distribution markers presented as Mean/ SD, p* statistically significant. t-test) 


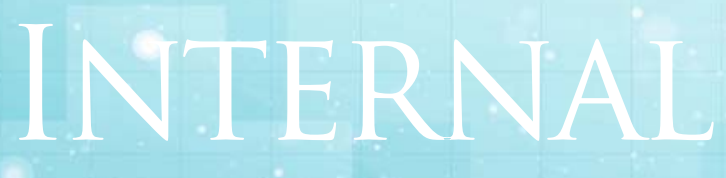

Original papers

in AUROC analyses for Hyaluronic acid, spleen size and prothrombin time (Figure 1).

Of note, liver stiffness measurements were performed in 29 out of the 41 patients, but only $22(46.3 \%)$ of them had valid measurements. 7 patients (17.1\%) were failures due to edema or ascites. Liver stiffness AUC was .708 with $95 \% \mathrm{Cl} 0,485$ 0,931 and $p .099$.

Several composite scores were calculated. FORNS and HEPASCORE had a discriminative power between the two groups (Table 2).

Correlations coefficients for the predictors that significantly associated with large varices are presented in Table 3.

\section{Multivariate analysis}

A binary regression was performed in order to evaluate the effect of TP, spleen size and hyaluronic acid on the likelihood of high-risk varices. The logistical model was statistically significant with a Chi-square value for the model of 21.831 ( $p$ <.0001). Only spleen size and hyaluronic acid added independently to the prediction value of the model. Odds ratios for a one-unit change in value for spleen size $(\mathrm{cm})$ and hyaluronic acid $(\mathrm{mcg} / \mathrm{I})$ were respectively 1.494 (1.002-2.227; $\mathrm{p}=.049)$ and $1.004(1.001-1.007 ; \mathrm{p}=.014)$. For each increment of $50 \mathrm{mcg} / \mathrm{I}$ of hyaluronic acid, the OR was 1.225 (1.042-1.440; $\mathrm{p}=$.014).
Predictive accuracy of clinically significant portal hypertension, comparison between Baveno criteria versus Hyaluronic acid, TP and Spleen size

Screening with the Baveno criteria was possible in all patients, even when one biomarker was missing. This composite predictor (decompensated cirrhosis, platelets less than $150,000 / \mathrm{mmc}$ or liver stiffens over $20 \mathrm{kPa}$ ) had a NPV of 0.75 and a PPV of 0.486 for high-risk varices (Table 4 ).

With a cut-off of $361.5 \mathrm{mcg} / \mathrm{I}$ (the maximum sum of specificity and sensitivity), hyaluronic acid had a PPV of 0.70 and a NPV of 0.88 . Compared to the Baveno discriminant, hyaluronic acid correctly reclassified 11 patients $(26 \%)$. It wrongly classified 2 of the patients $(4.9 \%)$ and did not change classification in 28 patients (68.3\%).

Spleen size, with a cut off of $13.5 \mathrm{~cm}$ (the maximum sum of specificity and sensitivity) had a VPP at 0.40 and a VPN at 0.785. Compared to the Baveno discriminant, spleen size correctly reclassified 1 patient $(2.5 \%)$. It wrongly classified 3 patients $(7.5 \%)$ and did not change classification in 37 (90\%). Prothrombin Time, with a cut off of $59.5 \%$ (maximal sum of sensitivity and specificity), had a PPV of 0.722 and a NPV of 0.74. Compared to the Baveno discriminant, TP correctly reclassified 8 patients (19.5\%). It wrongly classified 2 patients (4.9\%) and did not change classification in 31 (75\%). 


\begin{tabular}{|l|l|l|l|l|l|l|l|l|l|}
\hline & $\begin{array}{c}\text { Hyaluronic } \\
\text { acid }\end{array}$ & TP & Platelets & $\begin{array}{c}\text { Spleen } \\
\text { size }\end{array}$ & $\begin{array}{c}\text { Liver } \\
\text { stiffness }\end{array}$ & FORNS & $\begin{array}{l}\text { HEPA- } \\
\text { SCORE }\end{array}$ & MELD & LOK \\
\hline $\begin{array}{l}\text { High- } \\
\text { risk } \\
\text { varices }\end{array}$ & $0.600 * *$ & $-0.445^{* *}$ & -0.275 & $0.337^{*}$ & 0.245 & $0.339 *$ & $0.554^{* *}$ & 0.290 & 0.281 \\
\hline
\end{tabular}

Table 3. Correlation coefficient ( $r$ ) between non-invasive markers and high-risk varices $* P<0.05 * * P<0.01$ (Spearman's rho/ Pearson r)

\begin{tabular}{|c|c|c|c|c|c|}
\hline & $\begin{array}{l}\text { Cut off } \\
\text { value }\end{array}$ & Sensitivity & Specificity & PPV & NPV \\
\hline Liver stiffness* & $20 \mathrm{kPa}$ & 1 & 0.3 & 0.63 & 1 \\
\hline Platelets & $150000 / \mathrm{dl}$ & 0.83 & 0.27 & 0.48 & 0.66 \\
\hline Baveno criteria & & 0.94 & 0.14 & 0.5 & 0.75 \\
\hline $\begin{array}{l}\text { TP maximal sensitivity/ } \\
\text { specificity }\end{array}$ & $59.5 \%$ & 0.685 & 0.77 & 0.72 & 0.74 \\
\hline TP maximal sensitivity & $82 \%$ & 1 & 0.36 & 0.57 & 1 \\
\hline $\begin{array}{l}\text { Hyaluronic acid maximal } \\
\text { sensitivity / specificity }\end{array}$ & $361.5 \mathrm{mcg} / \mathrm{dl}$ & 0.89 & 0.68 & 0.70 & 0.88 \\
\hline $\begin{array}{l}\text { Hyaluronic acid maximal } \\
\text { sensitivity }\end{array}$ & $169 \mathrm{mcg} / \mathrm{dl}$ & 1 & 0.5 & 0.63 & 1 \\
\hline $\begin{array}{l}\text { Spleen size maximal } \\
\text { sensitivity/ specificity }\end{array}$ & $13.5 \mathrm{~cm}$ & 0.84 & 0.5 & 0.59 & 0.785 \\
\hline $\begin{array}{l}\text { Spleen size maximal } \\
\text { sensitivity }\end{array}$ & $8 \mathrm{~cm}$ & 1 & 0 & 0.46 & 1 \\
\hline
\end{tabular}

Table 4. Sensitivity and Specificity of markers of portal hypertension for 41 patients

* Liver stiffness in 22 patients 


\section{INTERNAL}

\section{Original papers}

\section{Discussion}

Our study showed that in non-viral cirrhosis, portal hypertension and high-risk varices are difficult to predict with classical tools. Easily available biomarkers like hyaluronic acid, spleen size and prothrombin time could be useful in this role.

The BAVENO $\mathrm{VI}^{(3)}$ consensus on portal hypertension proposed a guideline for esophageal varices screening in cirrhotic patients, that uses 3 categorical non-invasive discriminants: decompensated cirrhosis, liver stiffness and platelet value ${ }^{(9)}$. These 3 biomarkers were extracted from studies with rather large populations of viral hepatitis ${ }^{(3)}$. In our real-life study of predominantly steatosis related cirrhosis (alcoholic or non-alcoholic), the 3 discriminants alone or combined, failed to specifically isolate those patients carrying high-risk varices.

We were able to perform liver stiffness measurements in only 22 out of our 41 patients. In these patients, liver stiffness was predictive for high-risk varices with an AUC of .708, with a perfect sensitivity but a specificity that was only at $30 \%$. We considered failure was due to objective factors (ascites, obesity, wall oedema) in 9 patients, while in 12 patients, compliance was its main driver. Its availability is limited, and results are operator dependent and time consuming ${ }^{(17)}$.
Thrombocytopenia was a poor predictor of high-risk varices as it was present in 31 of the 41 patients. Its etiology in cirrhosis is complex ${ }^{(18)}$, with an expected prevalence of $64-84 \%$. Alcohol use ${ }^{(19,20)}$ impacts platelet count, regardless of cirrhosis. As such, we considered the result was predictable in our population.

If we applied the BAVENO VI criteria for portal hypertension screening in our study, we would have elicited a screening endoscopy in almost all patients and still would have missed out one patient with high-risk varices. Steatosis related cirrhosis patients probably harbor different hematological, biochemical and liver morphological and functional properties when compared to viral cirrhosis and the utility of most viral cirrhosis-derived biomarkers could be limited. We identified 3 different biomarkers that are good to excellent predictors of portal hypertension and high-risk varices in steatosis related disease: hyaluronic acid, TP and spleen size. Hepatic fibrosis is a dynamic, evolutionary process and seems to be the major driver of portal hypertension. Hyaluronic acid, a known marker of extracellular matrix anomalies incurrent in cirrhosis is also a potential marker of portal hypertension. Its role in the prediction of portal hypertension was evaluated in 1991. There was no correlation between hyaluronic acid values with portal hypertension, but the cut-off for 


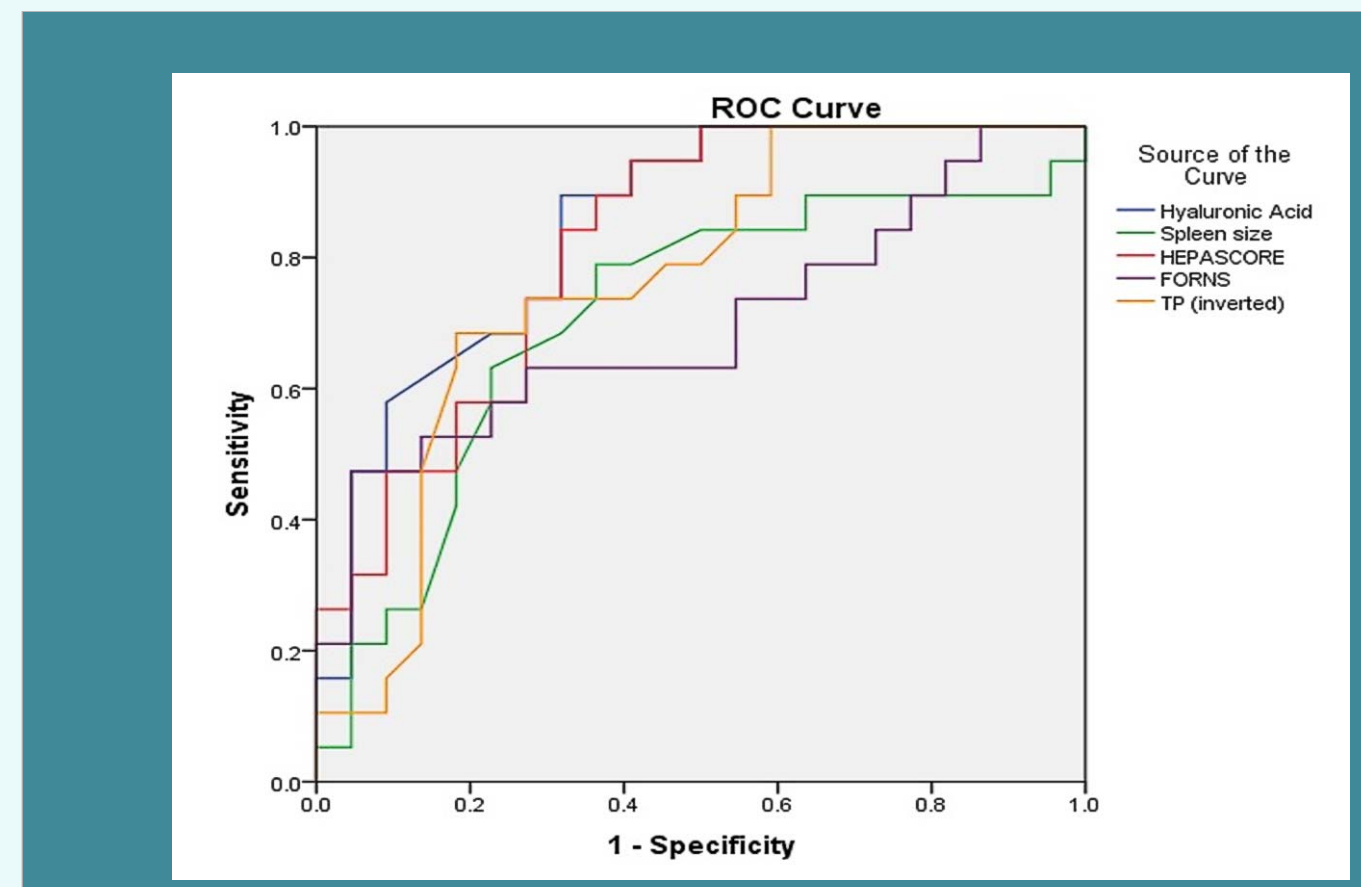

Figure 1. AUC of markers of high-risk varices: Hyaluronic acid (AUC .866; 95\% CI 0,730-0,964, p .000*); Spleen size (AUC .708; 95\% CI 0,541-0,875, p .023*); Hepascor (AUC 821; 95\% Cl 0.6940.947, p .000*); FORNS (AUC .696; 95\% Cl 0.529-0.864, p .032*); Inverted TP (AUC .763; $95 \% \mathrm{Cl}$ $\left.0,615-0,912, p .004^{*}\right)$

portal pressure was set at $5 \mathrm{mmHg}$, well below the accepted value of $10 \mathrm{mmHg}$ for clinical significance ${ }^{(18)}$. It has previously been associated with esophageal varices development risk in viral cirrhosis ${ }^{(21)}$. Hyaluronic acid was also an excellent predictor of the existence of high-risk varices in our study.

Prothrombin time, a hemostasis biomarker, amply used in cirrhosis, is not predictive for the coagulopathy of cirrhosis ${ }^{(22)}$ but it seems to predict variceal bleed ${ }^{(23)}$. This is probably due to its discriminative capacity for disease severity ${ }^{(24)}$ and also high-risk varices ${ }^{(25)}$. We found it had good predictive capacity in our population.

Spleen size, an easily available morphological marker of cirrhosis, had already been tested and proven to be an interesting marker, alone or in association with thrombocyte levels, for the prediction of high-risk varices in cirrhosis of different etiologies ${ }^{(26,27)}$. In our study, spleen size, but not platelet count, correlated with high-risk varices.

We also tested several multivariate scores of hepatic fibrosis or disease severity. Of them, HEPASCORE (versus FORNS, LOK, CHILD and MELD) was the best predictor of high-risk varices, but its discriminative power was surpassed by hyaluronic acid. We explained this finding by the fact that esophageal varices occur at portal pressures of more than $10-12 \mathrm{mmHg}$, well above the $5 \mathrm{mmHg}$ threshold of portal hypertension that was generally accepted in the derivation studies of these scores. If they were to be used as portal hypertension diagnosis tools, recalibration might be needed.

Our study had several limitations, in part due to "real life" conditions. Liver histology was seldom available, thus steatosis was probable and cirrhosis diagnosis was mainly based on non-invasive tests. In our study, 
liver stiffness measurement was realized in an outpatient setting, so failures depended on patient observance more than on clinical impediments. The size of the study probably triggered the omission of variables acknowledged to be associated with cirrhosis and portal hypertension.

\section{Conclusion}

In real-life settings and non-viral cirrhosis, confounders limit the use of the Baveno consensus criteria for screening for high-risk esophageal varices. Hyaluronic acid, spleen size and prothrombin size seem to be reliable markers. Their potency should be further proven in larger studies.

Conflict of interest, funding: The authors declare no conflict of interest. This research did not receive any specific grant from funding agencies in the public, commercial, ornon-profit sectors.

\section{References}

1. Trusheim, M.R., E.R. Berndt, and F.L. Douglas, Stratified medicine: strategic and economic implications of combining drugs and clinical biomarkers. Nat Rev Drug Discov, 2007. 6(4): p. 287-93.

2. Stein, G., Long-term therapy of chronic cor pulmonale. Dtsch Med Wochenschr, 1967. 92(42): p. 1922-4.

3. Augustin, S., et al., Expanding the Baveno VI criteria for the screening of varices in patients with compensated advanced chronic liver disease.
Hepatology, 2017. 66(6): p. 1980-1988.

4. El-Serag, H.B. and J.E. Everhart, Improved survival after variceal hemorrhage over an 11-year period in the Department of Veterans Affairs. Am J Gastroenterol, 2000. 95(12): p. 3566-73.

5. Carbonell, N., et al., Improved survival after variceal bleeding in patients with cirrhosis over the past two decades. Hepatology, 2004. 40(3): p. 652-9.

6. Garcia-Tsao, G., et al., Prevention and management of gastroesophageal varices and variceal hemorrhage in cirrhosis. AmJ Gastroenterol, 2007. 102(9): p. 2086-102.

7. Vallet-Pichard, A., et al., FIB-4: an inexpensive and accurate marker of fibrosis in HCV infection. comparison with liver biopsy and fibrotest. Hepatology, 2007. 46(1): p. 32-6.

8. Wai, C.T., et al., A simple noninvasive index can predict both significant fibrosis and cirrhosis in patients with chronic hepatitis C. Hepatology, 2003. 38(2): p. 518-26.

9. de Franchis, R. and V.I.F. Baveno, Expanding consensus in portal hypertension: Report of the Baveno VI Consensus Workshop: Stratifying risk and individualizing care for portal hypertension. J Hepatol, 2015. 63(3): p. 743-52.

10. Adams, L.A., et al., Hepascore: an accurate validated predictor of liver fibrosis in chronic hepatitis $C$ infection. Clin Chem, 2005. 51(10): p. 1867-73.

11. Kalantari, H., et al., Validation of hepascore as a predictor of liver fibrosis in patients with chronic hepatitis C infection. Hepat Res Treat, 2011. 2011: p. 972759.

12. Wiesner, R., et al., Model for end-stage liver disease (MELD) and allocation of donor livers. Gastroenterology, 2003. 124(1): p. 91-6.

13. Child, C.G. and J.G. Turcotte, Surgery and portal hypertension. Major Probl Clin Surg, 1964. 1: p. 1-85.

14. Pugh, R.N., et al., Transection of the oesophagus for bleeding oesophageal varices. BrJ Surg, 1973. 60(8): $p$. 646-9.

15. Charlson, M.E., et al., A new method of classifying prognostic comorbidity in longitudinal studies: 
development and validation. J Chronic Dis, 1987. 40(5): p. 373-83.

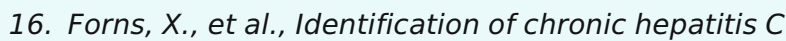
patients without hepatic fibrosis by a simple predictive model. Hepatology, 2002. 36(4 Pt 1): p. 986-92.

17. Pang, J.X., et al., The feasibility and reliability of transient elastography using Fibroscan $(R)$ : a practice audit of 2335 examinations. Can J Gastroenterol Hepatol, 2014. 28(3): p. 143-9.

18. Mitchell, O., et al., The pathophysiology of thrombocytopenia in chronic liver disease. Hepat Med, 2016. 8: p. 39-50.

19. Lindenbaum, J. and C.S. Lieber, Hematologic effects of alcohol in man in the absence of nutritional deficiency. N EnglJ Med, 1969. 281(7): p. 333-8.

20. Cowan, D.H. and J.D. Hines, Thrombocytopenia of severe alcoholism. Ann Intern Med, 1971. 74(1): p. 3743.

21. Fontana, R.J., et al., Factors that determine the development and progression of gastroesophageal varices in patients with chronic hepatitis $C$.
Gastroenterology, 2010. 138(7): p. 2321-31, 2331 e1-2. 22. Thachil, J., Relevance of clotting tests in liver disease. Postgrad Med J, 2008. 84(990): p. 177-81.

23. Schepis, F., et al., Which patients with cirrhosis should undergo endoscopic screening for esophageal varices detection? Hepatology, 2001. 33(2): p. 333-8.

24. Davis, J.R., et al., Estimate of Plasmodium falciparum sporozoite content of Anopheles stephensi used to challenge human volunteers. Am J Trop Med Hyg, 1989. 40(2): p. 128-30.

25. Islam, M.N., et al., Plasma Prothrombin Time and Esophageal Varices in Patients with Cirrhosis of Liver. Euroasian J Hepatogastroenterol, 2016. 6(1): p. 10-12.

26. Colli, $A_{\text {., et }}$ al., Platelet count, spleen length, and platelet count-to-spleen length ratio for the diagnosis of oesophageal varices in people with chronic liver disease or portal vein thrombosis. Cochrane Database Syst Rev, 2017. 4: p. CD008759.

27. Karatzas, A., et al., Nuon-invasive screening for esophageal varices in patients with liver cirrhosis. Ann Gastroenterol, 2018. 31(3): p. 305-314. 